\title{
ON THE VARIATIONS OF THE PLASMA VITAMIN A LEVEL AFTER THE ADMINISTRATION OF LARGE DOSES OF VITAMIN A IN LIVER DISEASE ${ }^{1}$
}

\author{
By HANS POPPER, FREDERICK STEIGMANN, AND SOL ZEVIN \\ (From the Cook County Hospital, the Departments of Pathology, Internal Medicine, Physiology, \\ and Pharmacology, University of Illinois College of Medicine, and the Cook \\ County Graduate School of Medicine, Chicago)
}

(Received for publication November 6, 1942)

The vitamin A level of the blood temporarily rises after the ingestion of high doses of vitamin A. This rise, as shown in the usual tolerance curve, is modified in various clinical conditions, such as liver disease $(1,2)$. Two explanations have been presented for the flat tolerance curves found in liver disease. (1) The vitamin A stores in the liver regulate the shape of the curve, the increase being less marked with livers poor in vitamin $\mathrm{A}$ and, consequently, having high avidity for it (Ralli et al. (2)). In this case, the tolerance curve would represent a saturation curve. Disturbed intestinal absorption leads to flat tolerance curves (Breese and McCoord (1)). According to this conception, the tolerance curve would represent an absorption curve. If tolerance curves are saturation curves, they represent a clinical index of the hepatic vitamin A concentration, which in humans cannot be judged by the fasting blood level alone (3). If they are absorption curves, they provide a means of studying deficiency of intestinal absorption.

In this paper, the influence of the various liver diseases on vitamin A tolerance curves is studied. Furthermore, the attempt is made to answer the above questions regarding the significance of the tolerance curve and to explain its change in liver disease.

\section{MATERIAL AND METHOD}

Tolerance curves were performed on 108 patients. Of these, 71 were patients suffering from diseases of the livet or biliary tract. The remaining 37 cases were used for comparison. Patients with hernia or fracture served as hospital controls. Patients with uncomplicated peptic ulcer, gastric carcinoma, and pyloric obstruction were added for comparison, as examples of abdominal disease, and because, in most of these, liver biopsy specimens

1 Supported by a grant from the Scientific Committee of the American Medical Association and from the S.M.A. Corporation, Chicago. could also be obtained. In 18 patients, the tolerance curves were performed several times during the course of the disease. In 6 patients, the curves were repeated immediately after the ingestion of several doses of 500,000 I.U. of vitamin $A$ ester, ${ }^{2}$ daily. In 3 others, the tolerance curves were repeated, 2 days after the last daily dose of 500,000 I.U. vitamin A was given. In 2 cases, the tolerance curve was checked after giving 1.0 gram of bile salts $^{3}$ simultaneously with the administration of 75,000 units of vitamin A. In 2 other cases, the tolerance curves were repeated twice; the first time on the day following the daily administration of 3.0 grams of bile salts ${ }^{3}$ for 4 days, the second time on the day following the intake of 1.2 grams of desoxycholic acid 4 for 4 days. In 3 patients, the tolerance curves were repeated on the day following the intake of 2.0 grams of bile salts (Wilson) 4 for the preceding 5 days. In 1 other patient, the tolerance curve was repeated on the day following the intake of 2.0 grams of cholic acid 4 for the preceding 5 days. The tolerance curve was performed by giving 75,000 I.U. of vitamin A ester in $2 \mathrm{cc}$. of corn oil mixed in fruit juice.

Following some orientation experiments, the vitamin A level of the plasma was determined before and 3,6 , and 24 hours after the administration of vitamin A. The determination was carried out by means of the Carr-Price reaction as described by Kimble (4), using 4 and, occasionally, 2 cc. of plasma. The measurements were made either by the Sheard-Sanford photoelectric colorimeter or by copper sulfate standards according to Josephs (5). The details of the methods were described in a previous paper (3) in which evidence was given that by using the proper technic, these two methods of measurement checked with each other satisfactorily. The measurements in the same patient were always performed by the same technic. Values below 2 micrograms per $100 \mathrm{cc}$. plasma were considered as zero levels.

In cases of suspected liver damage, at least 3 of the following determinations were done, as described in more detail in a previous paper (6): (1) Non-protein nitrogen, total protein, and globulin of the plasma; (2) plasma

${ }^{2}$ Distilled vitamin A concentrate (natural ester form distilled from fish liver and vegetable oil) containing 200,000 U.S.P. XI Units per gram, generously supplied by Distillation Products, Inc., Rochester, N. Y.

${ }^{8}$ Desicol, kindly supplied by Parke-Davis Co., Detroit.

4 Generously supplied by Wilson Laboratories, Chicago. 


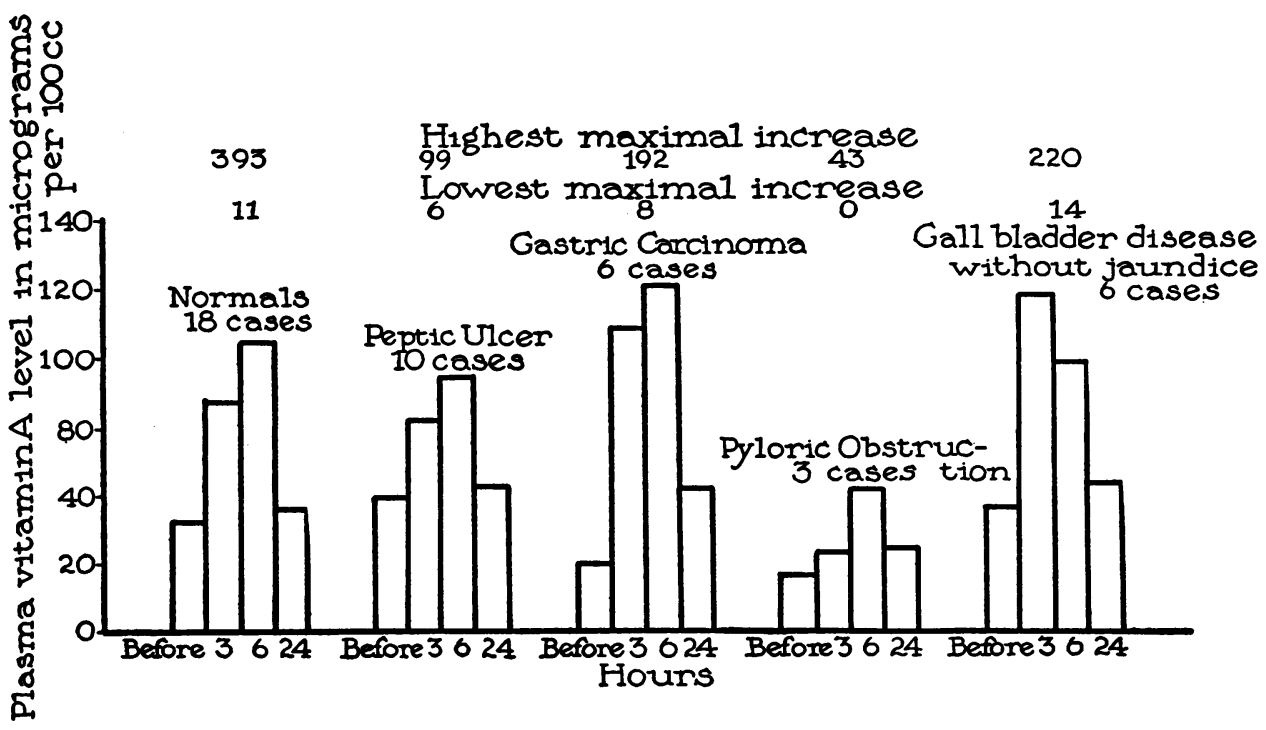

Fig. 1. Averages of the Plasma Vitamin A Levels Before, and 3, 6, and 24 hours After the Administration of 75,000 I.U. Vitamin A, in Normals and in Patients with Upper Abdominal Disease

prothrombin concentration (Quick's method); (3) blood cholesterol and cholesterol esters; (4) alkaline serum phosphatase; (5) oral hippuric acid test; (6) oral galactose tolerance test; (7) cephalin-cholesterol flocculation test. If at least 2 determinations yielded pathologic results, liver damage was assumed. In jaundice cases, the icteric index and the quantitative urobilinogen excretion in the urine, according to Watson's method (7), were also determined.

In 36 cases, liver biopsy specimens were taken, one or more days after performance of a tolerance curve, i.e., when the plasma level had usually returned to the fasting level. The biopsies were made during a laparotomy performed for various abdominal conditions. About 1 gram of tissue was excised from the convex surface of the liver. Part of the biopsy specimen was examined chemically for vitamin A, the same method being used as for plasma (3). The rest was studied by various chemical and histologic methods as reported elsewhere (3).

\section{RESULTS}

\section{A. Variation of tolerance curves in liver disease}

Figure 1 shows the average heights of the tolerance curves, after ingestion of 75,000 I.U. vitamin $\mathrm{A}$, in controls and in patients with abdominal conditions other than liver involvement. In the control cases, the blood level rose from an average preliminary level of 32 micrograms per $100 \mathrm{cc}$. plasma to an average of 85 micrograms.

To show the great individual variations in each group, the highest and lowest maximal rise in the entire group is recorded. By maximal rise is meant the difference between the fasting level and the highest level following ingestion of the vitamin $A$, without regard to the time interval. In the majority of cases tested, the maximal increase was found 6 hours after ingestion of vitamin $A$, in some after 3 hours. In all cases with definite rise after 3 or 6 hours, the 24-hour value was much lower than the highest level, even when there was no complete return to the fasting level.

Patients with uncomplicated peptic ulcer had curves similar to those of the controls. Their fasting plasma level was slightly higher than that of the controls. The few patients with gastric carcinoma without obstruction showed a preliminary level lower than the controls, but the rise of the curve was, on the average, higher than in the controls. In 3 cases of pyloric obstruction ( 2 due to ulcer and 1 to carcinoma), the fasting as well as the following levels were low. In patients with gall bladder disease without jaundice, no significant deviation from the normal was seen in their vitamin A tolerance curves.

In patients with liver disease, significant variations of the tolerance curves were obtained (Figure 2). In 6 patients with cholelithiasis and jaundice due to stone in the common duct, in whom routine clinical and laboratory examina- 
tions failed to show liver damage, the average of the fasting level was slightly lower than normal; the average response to the vitamin $A$ intake, however, was even higher than normal. In 4 patients with cholelithiasis and jaundice due to stone in the common duct, whose condition was complicated by biliary tract infection or prolonged jaundice, and in whom routine clinical and laboratory examinations did show liver damage, the average of the fasting level was low and the maximal rise much lower than in the cases without liver damage. Eleven patients with complete biliary obstruction due to malignancy of the extrahepatic bile ducts or head of pancreas had prolonged jaundice complicated by secondary hepatitis, as shown by function tests and histologic examination. In all but 3 of these patients, the fasting plasma level was zero. The response in the tolerance curve was very slight, and completely lacking in 5 cases. In these latter, the plasma level was zero throughout the entire curve.

Depression of the curve was also marked in 11 patients with acute hepatitis of varying etiology (catarrhal, arsphenamine, or cinchophen jaundice). Here again the fasting level was zero except for 3 cases. The tolerance curve also was quite flat.

In 15 patients with compensated cirrhosis without jaundice, in whom the clinical study and histologic examination (wherever possible) failed to reveal signs of acute hepatitis, the fasting vitamin A plasma level was relatively low, but the response to high vitamin $A$ intake was almost normal. In contrast to this, in 18 patients with cirrhosis, in whom jaundice indicated a superimposed acute hepatitis, the fasting level and the response shown in the tolerance curve were much lower.

\section{$B$. Change of tolerance curve during course of liver disease}

In 18 patients ( 5 with acute hepatitis, 8 with cirrhosis, 1 with complete biliary obstruction due to carcinoma of common duct, and 4 without liver disease), the tolerance curve was repeated 2 to 5 times during the course of the disease. In the patients without liver disease, no significant variations were observed. In the 5 patients with acute hepatitis, the tolerance curve became steeper and the fasting plasma level higher, concomitant with improvement of the clinical picture and the liver functions. In 3 of these, the fasting level and maximal increase were, in the recovery period, much higher than normal and both dropped to normal levels after complete recovery. In the patients with cirrhosis, the observations were extended up to 10 months; some of these patients markedly improved. The variations in fasting level and maximal increase were less characteristic than in the cases of hepatitis but generally showed a similar trend, rising with improvement

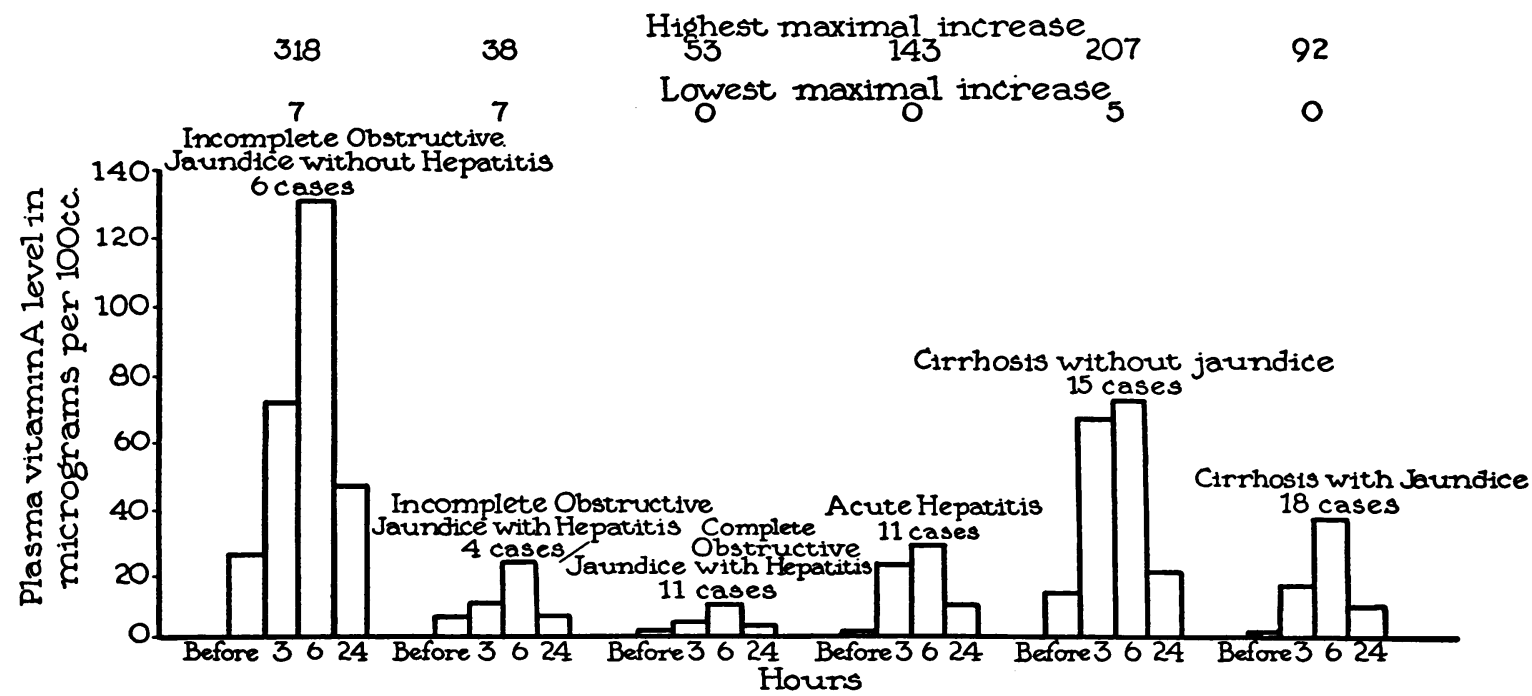

Fig. 2. Averages of the Plasma Vitamin A Levels Before, and 3, 6, and 24 hours After the Administration of 75,000 I.U. Vitamin A in Patients with Liver Disease or Jaundice 


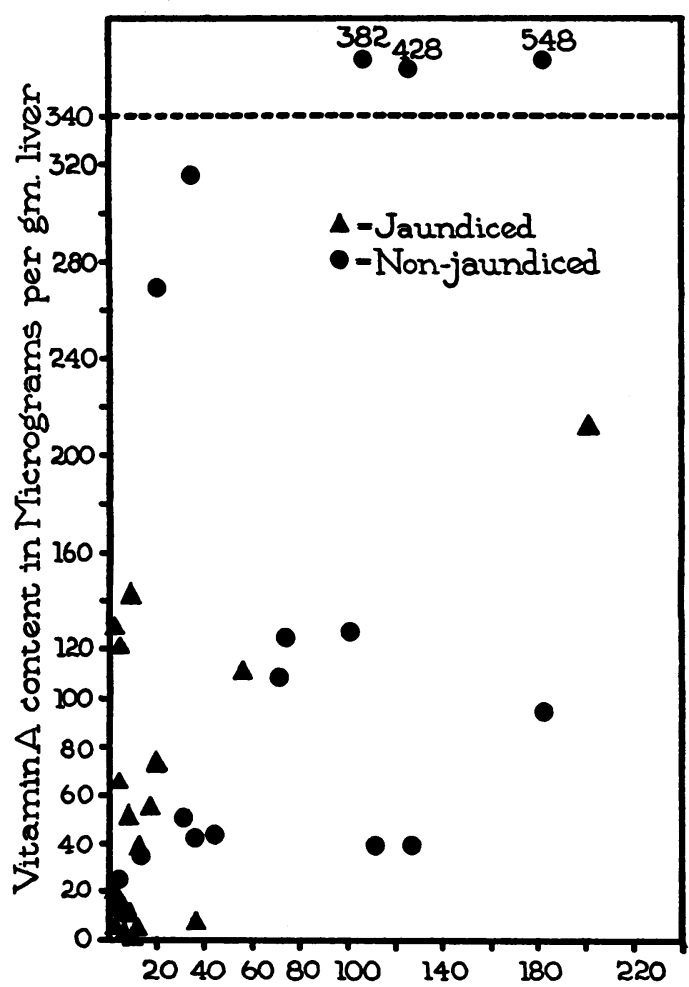

Maximal increase in Plasma VitaminA in Micrograms per $100 \mathrm{cc}$.

Fig. 3. Plot of the Maximal Increase of the Plasma Vitamin a Level Following Administration of 75,000 I.U of Vitamin A Against the Vitamin A Content of Liver Biopsy Specimens of the clinical picture and the liver function tests. Occasionally, during remissions, as a result of therapy, the fasting level would become higher and the tolerance curve steeper than normal. In the patient with carcinoma of the common duct and associated secondary hepatitis, no change occurred. Table I shows 4 representative cases.

\section{Cause of flat vitamin A tolerance curves}

In an attempt to explain whether the flatness of the tolerance curve in liver disease is due to impaired intestinal absorption or to increased rate of removal of vitamin A from the blood, the following relations were studied:

(a) Comparison between the vitamin $A$ content of the liver and the maximal increase of the tolerance curve. When the maximal increase of the plasma level in the tolerance curve is plotted against the hepatic vitamin A concentration, no direct relation is found (Figure 3). Occasionally, a relatively high response corresponded with a low liver content, which makes it improbable that the vitamin A tolerance curve is influenced by the saturation of the liver and excludes it as an index of the vitamin A stores of the liver.

(b) Influence on the tolerance curve of feeding large doses of vitamin $A$. Three patients received 500,000 I.U. vitamin A daily for 5 , and 3 others for 7 days. The vitamin $A$ tolerance was

TABLE I

Changes in the vitamin $A$ tolerance curve during clinical improvement of patients with liver disease

\begin{tabular}{|c|c|c|c|c|c|c|c|}
\hline \multirow{3}{*}{ Patient } & \multirow{3}{*}{ Diagnosis } & \multirow{3}{*}{ Date } & \multicolumn{4}{|c|}{ Vitamin A levels in plasma } & \multirow{3}{*}{ Icteric index } \\
\hline & & & \multirow{2}{*}{$\begin{array}{c}\text { Before } \\
\text { vitamin A } \\
\text { adminis- } \\
\text { tration }\end{array}$} & \multicolumn{3}{|c|}{ After administration of 75,000 I.U. vitamin A } & \\
\hline & & & & 3 hours & 6 hours & 24 hours & \\
\hline & & & \multicolumn{4}{|c|}{ micrograms } & \\
\hline M. B. & Cinchophen hepatitis & $\begin{array}{lr}\text { May } & 20 \\
\text { June } & 18 \\
\text { August } & 8\end{array}$ & $\begin{array}{l}11 \\
33 \\
22\end{array}$ & $\begin{array}{r}16 \\
66 \\
132\end{array}$ & $\begin{array}{l}33 \\
66 \\
88\end{array}$ & $\begin{array}{l}11 \\
33 \\
28\end{array}$ & $\begin{array}{r}211 \\
91 \\
16\end{array}$ \\
\hline J. K. & Catarrhal jaundice & $\begin{array}{lr}\text { August } & 6 \\
\text { August } & 19 \\
\text { August } & 27\end{array}$ & $\begin{array}{l}0 \\
0 \\
6\end{array}$ & $\begin{array}{r}0 \\
77 \\
66\end{array}$ & $\begin{array}{r}44 \\
86 \\
133\end{array}$ & $\begin{array}{r}6 \\
21 \\
8\end{array}$ & $\begin{array}{r}106 \\
66 \\
12\end{array}$ \\
\hline J. L. & Hepatitis & $\begin{array}{lr}\text { October } & 16 \\
\text { November } & 11 \\
\text { December } & 1\end{array}$ & $\begin{array}{r}0 \\
11 \\
21\end{array}$ & $\begin{array}{r}0 \\
212 \\
64\end{array}$ & $\begin{array}{r}16 \\
127 \\
85\end{array}$ & $\begin{array}{r}0 \\
29\end{array}$ & $\begin{array}{r}83 \\
234 \\
96\end{array}$ \\
\hline T. P. & $\begin{array}{l}\text { Cirrhosis without } \\
\text { jaundice }\end{array}$ & $\begin{array}{lr}\text { January } & 5 \\
\text { April } & 24 \\
\text { September } & 16 \\
\text { November } & 17 \\
\text { November } & 30\end{array}$ & $\begin{array}{l}13 \\
31 \\
26 \\
53 \\
64\end{array}$ & $\begin{array}{r}75 \\
47 \\
26 \\
233 \\
338\end{array}$ & $\begin{array}{r}63 \\
125 \\
220 \\
214 \\
381\end{array}$ & $\begin{array}{l}25 \\
31 \\
37 \\
85\end{array}$ & $\begin{array}{l}13 \\
11\end{array}$ \\
\hline
\end{tabular}


done before the administration of the vitamin A and was repeated on the day after the last dose. The average of the fasting levels in the second tolerance curves was markedly higher than in the preliminary-a rise from 32 to 73 micrograms. The average maximal increase in the second curve was only slightly higher than in the first-a rise from 91 to 103 micrograms (Figure 4).

Since the possibility existed that the fasting level of the second tolerance curve was influenced by the administration of 500,000 I.U. vitamin A on the preceding day, 3 other patients were given 500,000 I.U. vitamin A for 7 days, and a second tolerance curve was performed on the third day after the last dose of vitamin A. On this day, the fasting plasma level was markedly lower than on the day following the last dose of 500,000 I.U. vitamin $A$. The second tolerance curve in these patients did not vary markedly from the first one, although the liver stores should have been considerably increased (Table II).

(c) Influence of character of jaundice. To investigate the influence of the character of the jaundice on the tolerance curve, we studied (1) the relationship of the maximal increase and the fasting plasma vitamin A level to the icteric index, and (2) the influence of the administration of various bile acid preparations on the tolerance curve.

(1) Comparison of the icteric index with the fasting and maximal plasma level. As shown above, in jaundice with liver damage, the fasting

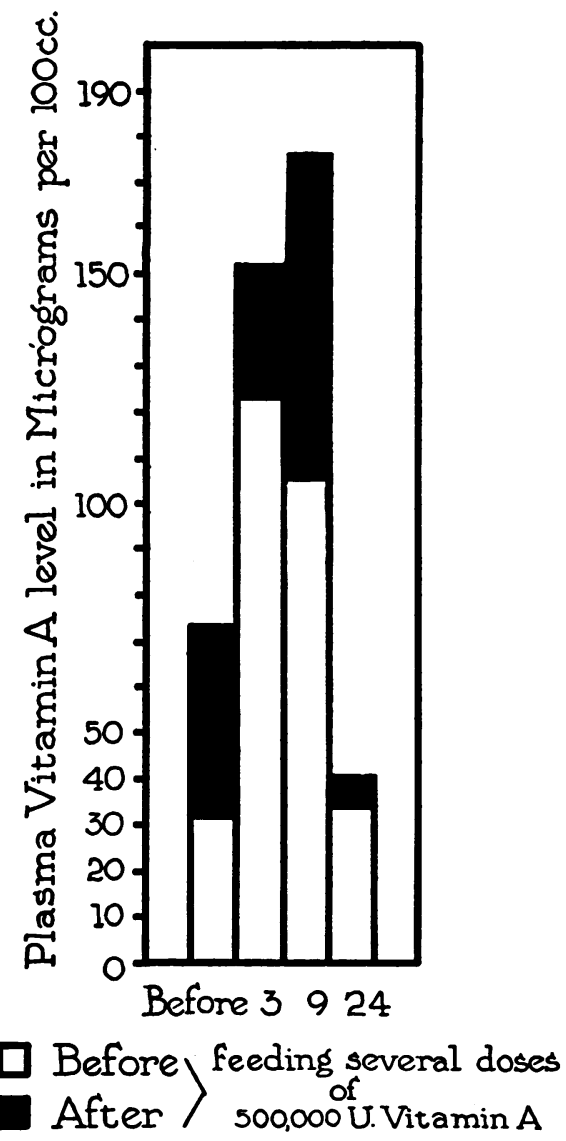

Fig. 4. Averages of the Plasma Vitamin A Levels Before, and 3, 6, ANd 24 hours After the Administration of 75,000 I.U. Vitamin A In 6 CASEs (REPRESENTED BY THE White columns). Repeat Tolerance Curves After Administration of 5 to 7 Daily Doses of 500,000 I.U. VitAMIN A (REPRESENTED BY WHITE PLUS BLACK COLUMNS)

TABLE II

Comparison of vitamin $A$ tolerance curves before and 3 days after the last dose of 500,000 I.U. of vitamin $A$ given daily for 7 days. The fasting level 1 and 2 days after the last dose of 500,000 I.U. of vitamin $A$ (8th and 9th days of test period) is also recorded

\begin{tabular}{|c|c|c|c|c|c|c|c|c|c|c|c|}
\hline \multirow{4}{*}{ Name } & \multicolumn{11}{|c|}{ Plasma vitamin A } \\
\hline & \multicolumn{4}{|c|}{$\begin{array}{l}\text { Preliminary test day } \\
\text { (1st tolerance curve) }\end{array}$} & \multirow[t]{3}{*}{$\begin{array}{l}\text { 1st to } \\
7 \text { th day }\end{array}$} & $\begin{array}{l}\text { 8th } \\
\text { day }\end{array}$ & $\begin{array}{l}9 \text { th } \\
\text { day }\end{array}$ & & $\begin{array}{r}\text { 10th } \\
\text { 2nd tolera }\end{array}$ & $\begin{array}{l}\text { day } \\
\text { ace curve) }\end{array}$ & \\
\hline & \multirow{2}{*}{$\begin{array}{c}\text { Fasting } \\
\text { level }\end{array}$} & \multicolumn{3}{|c|}{$\begin{array}{l}\text { After oral administration of } \\
75,000 \text { I.U. of vitamin A }\end{array}$} & & \multirow{2}{*}{$\begin{array}{l}\text { Fasting } \\
\text { level }\end{array}$} & \multirow{2}{*}{$\begin{array}{c}\text { Fasting } \\
\text { level }\end{array}$} & \multirow{2}{*}{$\begin{array}{c}\text { Fasting } \\
\text { level }\end{array}$} & \multicolumn{3}{|c|}{$\begin{array}{l}\text { After oral administration of } \\
\mathbf{7 5 , 0 0 0} \text { I.U. of vitamin A }\end{array}$} \\
\hline & & 3 hours & 6 hours & 24 hours & & & & & 3 hours & 6 hours & 24 hours \\
\hline $\begin{array}{l}\text { F. B. } \\
\text { L. F. } \\
\text { J. B. }\end{array}$ & $\begin{array}{l}64 \\
35 \\
48\end{array}$ & $\begin{array}{c}\text { microgram } \\
106 \\
87 \\
212\end{array}$ & $\begin{array}{c}\text { per } 100 \mathrm{cc} \\
96 \\
85 \\
180\end{array}$ & $\begin{array}{l}64 \\
41 \\
69\end{array}$ & $\begin{array}{c}500,000 \text { I.U. } \\
\text { vitamin } \mathrm{A} \\
\text { daily }\end{array}$ & $\begin{array}{l}76^{m i c} \\
76 \\
216\end{array}$ & $\begin{array}{c}\text { rams per } \\
45 \\
69 \\
115\end{array}$ & $\begin{array}{l}62 . \\
40 \\
96\end{array}$ & $\begin{array}{c}\text { micrc } \\
186 \\
65 \\
230\end{array}$ & $\begin{array}{c}\text { grams per } \\
144 \\
65 \\
251\end{array}$ & $\begin{array}{r}100 c c . \\
82 \\
42 \\
110\end{array}$ \\
\hline Average & 44 & 135 & 121 & 58 & & & & 66 & 160 & 153 & 78 \\
\hline
\end{tabular}




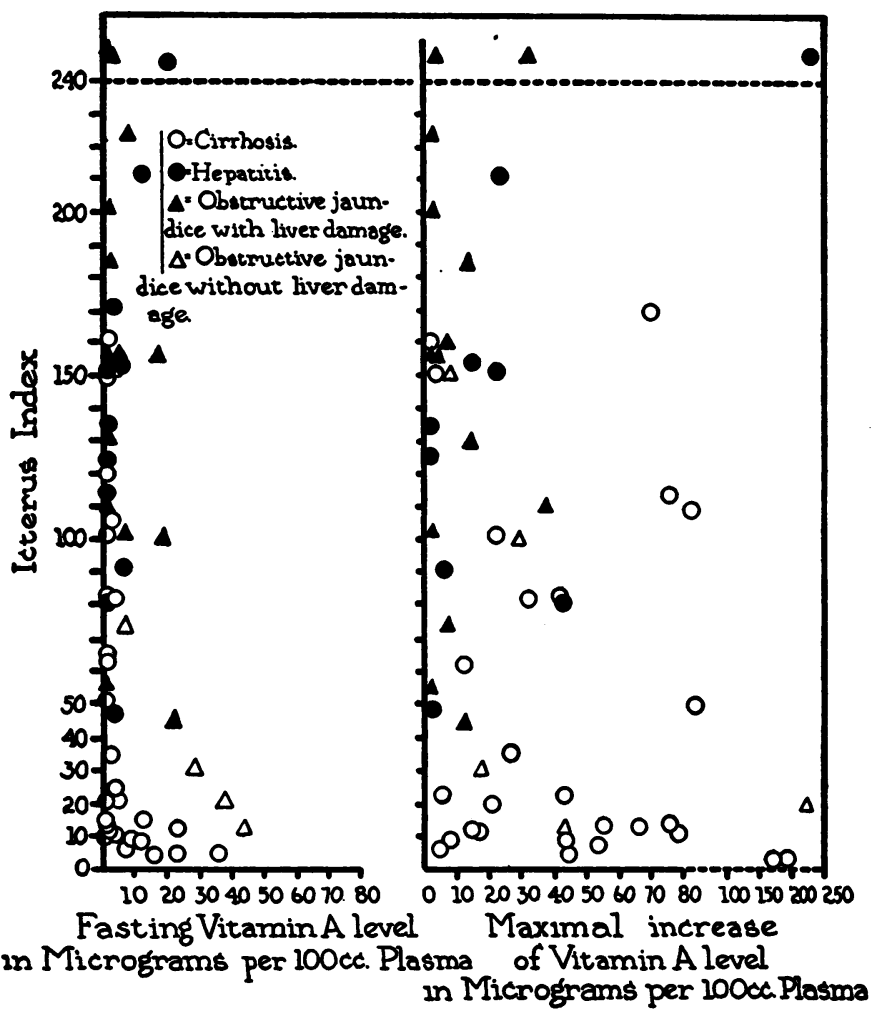

Fig. 5. Plot of the Fasting Plasma Vitamin A Levels and Their Maximal Increase Following the Administration of 75,000 I.U. Vitamin A Against the ICTERIC IndeX

plasma vitamin A level was lower and the tolerance curves were flatter than in jaundice without liver damage (Figure 2). A direct comparison of the plasma vitamin A level with the degree of jaundice showed that usually the higher the icteric index, the lower the fasting blood level (Figure 5). In parenchymatous jaundice, however (as in compensated cirrhosis), the plasma level was low, even with a low icteric index.

A consistent relationship between the icteric index and the maximal increase has not been noted; flat tolerance curves were found with both low and high icteric indices. These findings indicate that flat tolerance curves and low fasting levels are more related to the degree of liver damage than to the height of the icterus.

(2) Bile acid administration. The character of the jaundice may also be determined by the absence of bile acids from the bile. Since no clinical methods are available to determine the amount of bile acids present in the bile, we gave bile acid preparations to 8 patients with liver disease to see whether the addition of such preparations would change flat tolerance curves. The bile acids were given-as described above-either simultaneously or for 4 or 5 successive days before the administration of vitamin $A$. Conjugated bile salts of hog bile (desicol) and of ox bile (bile salts Wilson), and free, non-oxidized acid (desoxycholic acid and cholic acid) were used. The data in Table III indicate that the bile acids administered exerted no definite influence in any of the patients.

\section{DISCUSSION}

The observation that in some liver diseases (juvenile catarrhal jaundice (1) and cirrhosis (2)), the plasma vitamin A level rises only slightly after the intake of a large dose of vitamin A was confirmed and extended to a variety of liver diseases. Our data indicate that the flatness of the tolerance curve in those conditions runs parallel to the degree of liver damage. Thus, in incomplete biliary obstruction due to 
stone, without hepatitis, the tolerance curve appears nearly normal. On the other hand, in incomplete biliary obstruction with hepatitis, the curve is definitely flatter, and in complete (malignant) obstruction where the hepatitis is even more marked, practically no response to the vitamin A intake is noted. Similarly, in arrested cirrhosis, the tolerance curve is only slightly flatter than in the normal, whereas in cirrhosis with superimposed hepatitis, the curve is flat as in acute hepatitis. In upper abdominal diseases, such as gastric carcinoma, peptic ulcer, and gall bladder disease without jaundice, the tolerance curve appears nearly normal.

The influence of liver damage on the tolerance curve is also illustrated by the return of the tolerance curve to normal during the recovery stage of patients with liver disease, which finding agrees with the previous experience of Breese and McCoord and Clausen and McCoord with children suffering from acute catarrhal jaundice $(1,8)$. These authors observed occasionally in the recovery stage a rise in the tolerance curve, even higher than normal. Some of our patients showed similar behavior with a return to normal ranges upon complete recovery.

What causes the flat tolerance curve in liver damage? To answer this question one would have to decide whether the shape of the tolerance curve depends on the intestinal absorption of vita$\min A$, or on the saturation of the liver with vita$\min A$, the latter determining how much vitamin A the liver takes up from the blood stream.

As shown elsewhere $(3,9)$, the fasting plasma vitamin A level did not necessarily mirror the hepatic vitamin A concentration in the human. It was, therefore, interesting to determine whether there exists a relationship between the maximal increase in the tolerance curve and the vitamin A concentration in the liver as determined on liver biopsy specimens. It was found that high tolerance curves were not necessarily associated with high liver depots and, hence, are not explained by the saturation of the liver with vitamin A. On the other hand, low curves were not always associated with depleted liver stores and are, there-

TABLE III

Influence of bile acid administration upon the vitamin $A$ tolerance curve in patients with jaundice

\begin{tabular}{|c|c|c|c|c|c|c|}
\hline \multirow{3}{*}{ Patient } & \multirow{3}{*}{ Diagnosis } & \multirow{3}{*}{ Preparation } & \multicolumn{4}{|c|}{ Vitamin A levels in plasma } \\
\hline & & & \multirow{2}{*}{$\begin{array}{l}\text { Before } \\
\text { vitamin A } \\
\text { adminis- } \\
\text { tration }\end{array}$} & \multicolumn{3}{|c|}{ After administration of 75,000 I.U. of vitamin A } \\
\hline & & & & 3 hours & 6 hours & 24 hours \\
\hline & & & \multicolumn{4}{|c|}{ micrograms } \\
\hline J. K. & Cholangitis & 1 gram desicol & $\begin{array}{l}0 \\
0\end{array}$ & $\begin{array}{l}0 \\
7\end{array}$ & $\begin{array}{r}13 \\
8\end{array}$ & $\begin{array}{l}\mathbf{0} \\
\mathbf{0}\end{array}$ \\
\hline F. G. & Cirrhosis with jaundice & 1 gram desicol & $\begin{array}{l}0 \\
0\end{array}$ & $\begin{array}{l}0 \\
0\end{array}$ & $\begin{array}{r}9 \\
11\end{array}$ & $\begin{array}{l}\mathbf{0} \\
\mathbf{0}\end{array}$ \\
\hline F. W. & Cirrhosis with jaundice & $\begin{array}{c}0 \\
12 \text { grams desicol } \\
4.8 \text { grams desoxycholic acid }\end{array}$ & $\begin{array}{l}\mathbf{0} \\
\mathbf{0} \\
\mathbf{0}\end{array}$ & $\begin{array}{r}42 \\
3 \\
22\end{array}$ & $\begin{array}{l}42 \\
55 \\
31\end{array}$ & $\begin{array}{r}3 \\
6 \\
12\end{array}$ \\
\hline M. G. & Cirrhosis with jaundice & $\begin{array}{c}0 \\
12 \text { grams desicol } \\
\text { 4.8 grams desoxycholic acid }\end{array}$ & $\begin{array}{l}3 \\
4 \\
0\end{array}$ & $\begin{array}{r}11 \\
11 \\
0\end{array}$ & $\begin{array}{l}34 \\
77 \\
44\end{array}$ & $\begin{array}{r}17 \\
4 \\
0\end{array}$ \\
\hline M. B. & Hepatitis & 10 grams bile salts Wilson & $\begin{array}{l}5 \\
0\end{array}$ & $\begin{array}{l}5 \\
0\end{array}$ & $\begin{array}{r}11 \\
0\end{array}$ & $\begin{array}{r}17 \\
0\end{array}$ \\
\hline T. L. & Cirrhosis with jaundice & $\begin{array}{l}0 \\
10 \text { grams bile salts Wilson }\end{array}$ & $\begin{array}{l}14 \\
16\end{array}$ & $\begin{array}{l}74 \\
37\end{array}$ & $\begin{array}{l}67 \\
53\end{array}$ & $\begin{array}{l}17 \\
23\end{array}$ \\
\hline F. R. & Obstructive jaundice & $\begin{array}{l}0 \\
10 \text { grams bile salts Wilson }\end{array}$ & $\begin{array}{l}\mathbf{0} \\
\mathbf{0}\end{array}$ & $\begin{array}{l}\mathbf{0} \\
\mathbf{0}\end{array}$ & $\begin{array}{l}\mathbf{0} \\
\mathbf{0}\end{array}$ & $\begin{array}{l}\mathbf{0} \\
\mathbf{0}\end{array}$ \\
\hline E. $K$. & Cirrhosis with jaundice & 10 grams cholic acid & $\begin{array}{l}0 \\
7\end{array}$ & $\begin{array}{l}10 \\
19\end{array}$ & $\begin{array}{l}22 \\
24\end{array}$ & $\begin{array}{l}16 \\
15\end{array}$ \\
\hline
\end{tabular}


fore, not caused by an increased uptake of vitamin A from the blood by the liver. Apparently then, the tolerance curve is not a criterion of the vitamin A depots in the liver. This conclusion is supported also by the fact that the difference in the tolerance curves taken before and after saturating the liver by administering repeatedly huge doses of vitamin $\mathrm{A}$-which have been found by previous experiments to increase markedly the liver vitamin A stores (3)-is not as striking as one would expect if liver saturation had an influence on the tolerance curve.

Since saturation of the liver does not play a decisive part, impaired intestinal absorption of vitamin $A$, as assumed by Breese and McCoord (1), would present itself as the responsible factor for the flat curve. The low tolerance curves found in children with celiac disease $(10,11)$ and in patients with sprue $(12,13)$ point in the same direction. The findings in pyloric obstruction reported here also support this idea.

What impairs intestinal absorption of vitamin $\mathrm{A}$ in liver disease? The most obvious cause would appear to be jaundice with the concomitant interference with bile secretion. However, the lack of correlation between the maximal increase in the tolerance curves and the degree of icterus points more to liver damage as the cause.

The rôle of bile salts in the intestinal absorption of vitamin A must be considered since they may be altered or absent in liver disease. Experiments on rats with obstructive jaundice indicated that the absorption of carotene, but not of vitamin $A$, was interfered with by the lack of bile acids (14). Breese and McCoord (1), however, improved vitamin A absorption in acute catarrhal jaundice of children by the administration of bile salts. Their experience and ours, that in the recovery stage of hepatitis the absorption of vitamin $A$ is better than normal, would suggest that an increased bile salt excretion during this stage is the responsible factor. Our attempts, however, to correct the flat tolerance curve of adult jaundiced patients were not successful either when we used ox or hog bile salts or when we gave desoxycholic acid which is supposedly the most active bile acid for fat and vitamin absorption (15 to 17). The doses given were the highest tolerated by the patient. It is, however, possible that the administration of bile acid preparations for 5 days is not sufficient, in adult jaundiced patients, to influence vitamin A absorption, or that the preparations which we used did not contain in sufficient quantity the particular bile acid which in humans might be most effective for vitamin $\mathrm{A}$ absorption.

There still remains the question whether the flat tolerance curve in liver damage is due to an impairment of the intestinal absorption or to a mere reduction of it, due to destruction of vitamin A within the intestinal lumen. Recent studies (18) as to the influence of antioxidantia on the vitamin A metabolism emphasize the possibility of the oxidative destruction of vitamin $A$ in the intestine or even in the tissues.

Poor intestinal absorption in liver disease may explain the low vitamin A levels in blood (19) and liver (19 to 21 ) in chronic liver disease as in cirrhosis. On the other hand, in acute liver damage, impaired absorption alone is not sufficient to explain the low blood level found in these cases $(1,22,23)$, since, when healthy subjects are given a vitamin A-free diet-which is comparable to absorption impairment-months are required to obtain a marked reduction in the blood level (24, $25,26)$. In acute hepatitis, a second factor is present, namely, the inability of the liver to release vitamin A to the blood, which phenomeno is discussed in another paper (3).

\section{SUMMARY}

(1) The rise of the blood vitamin A level following the ingestion of 75,000 I.U. vitamin A (tolerance curve) was investigated in normals and in patients with liver disease and other upper abdominal disease.

(2) In liver diseases, the tolerance curve is much flatter than in normals, paralleling the degree of liver damage. It is less flattened in arrested cirrhosis without jaundice and in biliary obstruction without hepatitis, than in toxic hepatitis or cirrhosis with jaundice or in biliary obstruction with secondary hepatitis. With clinical improvement, the tolerance curve and the low fasting plasma vitamin A level of patients with liver damage return toward normal.

(3) By comparison of the tolerance curves with the vitamin A content of liver biopsy specimens from the same patients, and, furthermore, by com- 
parison of the tolerance curves before and after saturating the liver with large amounts of vitamin A, and by study of the tolerance curves in conditions known to be associated with disturbed intestinal absorption, evidence was obtained that the tolerance curves are not related to the liver saturation of vitamin A but rather to the efficiency of vitamin A absorption from the intestine.

(4) The disturbed intestinal absorption of vita$\min \mathrm{A}$ in liver disease is not primarily related to the degree of jaundice but rather to the degree of liver damage. The authors have been unable to correct the absorption damage by the administration of various bile acid preparations. Nevertheless, the possibility cannot be excluded that in liver damage, the absence of some particular bile acid from the intestine is the cause of the faulty absorption of vitamin A.

\section{BIBLIOGRAPHY}

1. Breese, B. B., and McCoord, A. B., Vitamin A absorption in catarrhal jaundice. J. Pediat., 1940, 16, 139.

2. Ralli, E. P., Bauman, E., and Roberts, L. B., The plasma levels of vitamin $A$ after the ingestion of standard doses: Studies in normal subjects and patients with cirrhosis of the liver. J. Clin. Invest., 1941, 20, 709.

3. Popper, H., Steigmann, F., Meyer, K. A., and Zevin, S., Relation between hepatic vitamin A concentration and plasma vitamin A levels in humans. Arch. Int. Med., In press.

4. Kimble, M. S., Photocolorimetric determination of yitamin $\mathrm{A}$ and carotene in human plasma. J. Lab. and Clin. Med., 1939, 24, 1055.

5. Josephs, H. W., Studies in vitamin A. Relation of vitamin $A$ and carotene to serum lipids. Bull. Johns Hopkins Hosp., 1939, 65, 112.

6. Meyer, K. A., Steigmann, F., Popper, H., and Walters, H. W., Influence of hepatic function on metabolism of vitamin A. Arch. Surg., 1943, 47, 26.

7. Watson, C. J., Studies of urobilinogen. 1. An improved method for the quantitative estimation of urobilinogen in urine and feces. Am. J. Clin. Path., 1936, 6, 458.

8. Clausen, S. W., and McCoord, A. B., The carotinoids and vitamin A of the blood. J. Pediat., 1938, 13, 635.

9. Meyer, K. A., et al., Comparison of vitamin A of liver biopsy specimens with plasma vitamin $A$ in man. Proc. Soc. Exper. Biol. and Med., 1942, 49, 589.
10. Breese, B. B., Jr., and McCoord, A. B., Vitamin A absorption in celiac disease. J. Pediat., 1939, 15, 183.

11. May, C. D., and McCreary, J. F., The absorption of vitamin A in celiac disease. J. Pediat., 1941, 18, 200.

12. Adlersberg, D., and Sobotka, H., Fat and vitamin A absorption in sprue and jejunoileitis. Gastroenterol., 1943, 1, 357.

13. Ingelfinger, F. J., and Moss, R. E., Studies on the absorption defect in sprue. J. Clin. Invest., 1942, 21, 621.

14. Greaves, J. D., and Schmidt, C. L. A., On the absorption and utilization of carotene and vitamin $A$ in choledochocolonostomized vitamin A deficient rats. Am. J. Physiol., 1935, 111, 492.

15. Greaves, J. D., and Schmidt, C. L. A., Relation of certain bile acids to absorption of beta-carotene in the rat. Proc. Soc. Exper. Biol. and Med., 1937, 36, 434.

16. Butt, H. R., The absorption of the fat-soluble vitamins. Am. J. Digest. Dis., 1939, 6, 127.

17. Ivy, A. C., and Berman, A. L., The rationale of bile salt therapy in biliary tract disease. Minnesota Med., 1939, 22, 815.

18. Hickman, K. C. D., Harris, P. L., and Woodside, M. R., Interrelationship of vitamins $\mathrm{A}$ and $\mathrm{E}$. Nature, 1942, 150, 91.

19. Haig, C., and Patek, A. J., Jr., Vitamin A deficiency in Laennec's cirrhosis. The relative significance of plasma vitamin A and carotinoid levels and the dark adaptation time. J. Clin. Invest., 1942, 21, 309.

20. Moore, T., The vitamin A reserve of the adult human being in health and disease. Biochem. J., 1937, 31, 155.

21. Ralli, E. P., Papper, E., Paley, K., and Bauman, E., Vitamin $\mathbf{A}$ and carotene content of human liver in normal and diseased subjects. Arch. Int. Med., 1941, 68, 102.

22. Lasch, F., Ueber den Vitamin A-Spiegel im Blute bei Leberkrankheiten. Klin. Wchnschr., 1938, 17, 1107.

23. Lindqvist, T., Studien ueber das Vitamin A beim Menschen. Acta med. Scandinav., 1938, Suppl. 97, 1.

24. Murrill, W. A., Horton, P. B., Leiberman, E., and Newburgh, L. H., Vitamin A and carotene metabolism in diabetics and normals. J. Clin. Invest., 1941, 20, 395.

25. Steininger, G., Roberts, L. J., and Brenner, S., Vita$\min A$ in the blood of normal adults. The effect of a depletion diet on blood values and biophotometer readings. J. A. M. A., 1939, 113, 2381.

26. Wald, G., Brouha, L., and Johnson, R. E., Experimental human vitamin $A$ deficiency and the ability to perform muscular exercise. Am. J. Physiol., 1942, 137, 551. 